\title{
Agrococcus lahaulensis sp. nov., isolated from a cold desert of the Indian Himalayas
}

Correspondence
S. Mayilraj
mayil@imtech.res.in

Correspondence

mayil@imtech.res.in

\author{
S. Mayilraj, ${ }^{1}$ K. Suresh, ${ }^{1}$ P. Schumann, ${ }^{2}$ R. M. Kroppenstedt ${ }^{2}$ and H. S. Saini ${ }^{3}$ \\ ${ }^{1}$ Microbial Type Culture Collection and Gene Bank (MTCC), Institute of Microbial Technology, \\ Sector 39-A, Chandigarh, 160 036, India \\ ${ }^{2}$ DSMZ - Deutsche Sammlung von Mikroorganismen und Zellkulturen GmbH, Mascheroder \\ Weg 1b, D-38124 Braunschweig, Germany \\ ${ }^{3}$ Department of Microbiology, Guru Nanak Dev University (GNDU), Amritsar, 143 005, India
}

\begin{abstract}
The taxonomic position of a lemon-yellow-pigmented actinobacterium, strain $\mathrm{K} 22-21^{\top}$, isolated from a soil sample from Lahaul-Spiti Valley in the Indian Himalayas, was determined using a polyphasic approach. The strain had phenotypic and chemical properties that were consistent with its classification in the genus Agrococcus. Alignment of the 16S rRNA gene sequence of strain K22-21 ${ }^{\top}$ with sequences from Agrococcus jenensis DSM 9580 ${ }^{\top}$, Agrococcus baldri DSM $14215^{\top}$ and Agrococcus citreus DSM $12453^{\top}$ revealed similarities of $98 \cdot 5,96 \cdot 8$ and $96 \cdot 6 \%$, respectively. However, the level of DNA-DNA relatedness between strain $\mathrm{K} 22-21^{\top}$ and $A$. jenensis was $55.1 \%$. The novel strain could be distinguished from type strains of the three species of the genus Agrococcus using DNA-DNA relatedness and phenotypic data. Based on these differences, strain K22-21 $1^{\top}$ (=MTCC $7154^{\top}=$ DSM $17612^{\top}$ ) should be classified as the type strain of a novel species of Agrococcus, for which the name Agrococcus lahaulensis sp. nov. is proposed.
\end{abstract}

The genus Agrococcus forms a separate lineage within the family Microbacteriaceae (Park et al., 1993; Rainey et al., 1994; Stackebrandt et al., 1997; Suzuki et al., 1997). At the time of writing, the genus Agrococcus comprises three species, Agrococcus jenensis (Groth et al., 1996), Agrococcus citreus (Wieser et al., 1999) and Agrococcus baldri (Zlamala et al., 2002).

Strain $\mathrm{K} 22-21^{\mathrm{T}}$ was isolated from a soil sample collected from the Lahaul-Spiti Valley in the Indian Himalayas by the dilution-plating technique on tryptic soy agar medium (TSA; HiMedia) and maintained as glycerol stocks at $-70^{\circ} \mathrm{C}$. The reference strains Agrococcus jenensis MTCC $6413^{\mathrm{T}}$, Agrococcus citreus MTCC $6410^{\mathrm{T}}$ and Agrococcus baldri MTCC $6457^{\mathrm{T}}$ were obtained from the Microbial Type Culture Collection and Gene Bank (MTCC), Chandigarh, India.

Colony and cell morphology were studied according to standard methods (Murray et al., 1994). Gram reaction was determined using a Gram staining kit (HiMedia) according to the manufacturer's instructions. Growth at different

The GenBank/EMBL/DDBJ accession number for the 16S rRNA gene sequence of strain $\mathrm{K} 22-21^{\top}$ is $\mathrm{DQ} 156908$.

The fatty acid compositions of strain $\mathrm{K} 22-21^{\top}$ and the type strains of the three known Agrococcus species are available as supplementary material in IJSEM Online. temperatures, $\mathrm{pH}$ and $\mathrm{NaCl}$ concentrations was examined by growing the strain on basal TSA medium. Catalase production, oxidase activity (with $N, N, N^{\prime}, N^{\prime}$-tetramethyl-pphenylenediamine dihydrochloride) and urea hydrolysis were determined as described by Cowan \& Steel (1965). The following characters were analysed as described by Smibert \& Krieg (1994): decomposition of casein, gelatin, Tween 20 and starch; indole and hydrogen sulfide production; methyl red and Voges-Proskauer tests; acid-fast and endospore staining; and motility. Nitrate reduction was assayed as described by Lanyi (1987). Utilization of various carbon sources was tested using Biolog GP2 MicroPlates; plates were used according to the manufacturer's instructions with the modification that TSA medium was used instead of Biolog Universal Growth agar medium. The inoculated plates were incubated for $24 \mathrm{~h}$ and results were read with a MicroPlate Reader using Microlog 4.2 software to perform automated reading. Acid production from various sugars was tested as described by Smith et al. (1952). Standard procedures were used to determine the cell-wall sugars (Staneck \& Roberts, 1974). Preparation of cell walls and determination of peptidoglycan structure were done as described by Schleifer \& Kandler (1972), with the modification that TLC on cellulose sheets (Merck) was used instead of paper chromatography. Polar lipids and menaquinones were extracted and analysed according to Minnikin et al. (1984) and Kroppenstedt (1982). The absence of mycolic acids was demonstrated by TLC (Minnikin \& Goodfellow, 
Table 1. Physiological and biochemical properties of strain $\mathrm{K} 22-21^{\top}$ and type strains of Agrococcus species

Strains: 1, K22-21 ${ }^{\mathrm{T}}$; 2, A. baldri MTCC $6457^{\mathrm{T}}$; 3, A. citreus MTCC $6410^{\mathrm{T}}$; 4, A. jenensis MTCC $6413^{\mathrm{T}}$. All data are from the present study. All four strains do not produce endospores, are catalase-positive and oxidase-negative and grow in the presence of 2 and $4 \% \mathrm{NaCl}$. In Biolog GP2 tests, all are positive for utilization of L-arabinose, D-fructose, D-mannitol, D-ribose and D-xylose and all are negative for utilization of $\alpha$-cyclodextrin, $\beta$-cyclodextrin, glycogen, inulin, mannan, Tweens 40 and $80, N$-acetyl-D-glucosamine, $N$-acetyl- $\beta$-D-mannosamine, amygdalin, D-arabitol, arbutin, D-cellobiose, L-fucose, D-galactose, D-galacturonic acid, gentiobiose, myo-inositol, $\alpha$-D-lactose, lactulose, maltose, D-melezitose, D-melibiose, methyl $\alpha$-D-galactoside, methyl $\beta$-D-galactoside, 3-methyl glucose, methyl $\alpha$-D-glucoside, methyl $\beta$-D-glucoside, methyl $\alpha$-D-mannoside, palatinose, D-raffinose, salicin, sedoheptulosan, stachyose, sucrose, D-trehalose, xylitol, acetic acid, $\alpha$ - and $\beta$-hydroxybutyric acids, $p$-hydroxyphenylacetic acid, $\alpha$-ketoglutaric acid, $\alpha$-ketovaleric acid, lactamide, D-lactic acid methyl ester, L-lactic acid, D- and L-malic acid, pyruvic acid methyl ester, succinic acid monomethyl ester, propionic acid, pyruvic acid, succinamic acid, succinic acid, $N$-acetyl-L-glutamic acid, D- and L-alanine, L-alanyl glycine, L-asparagine, L-glutamic acid, glycyl L-glutamic acid, L-serine, L-pyroglutamic acid, putrescine, 2,3-butanediol, uridine, AMP, TMP, UMP, $\alpha$-D-glucose 1-phosphate, D-glucose 6-phosphate and DL- $\alpha$-glycerol phosphate as sole carbon sources. Acid is produced from D-fructose and D-trehalose ${ }^{a_{\star}}$ but not from D-galactose, D-glucose, salicin, $\mathrm{D}_{\text {-xylose }}^{b}$ or myo-inositol. Negative for growth at $\mathrm{pH} 5 \cdot 2$, utilization of citrate, methyl red and VogesProskauer tests, nitrate reduction, indole and urease production. +, Positive; -, negative; w, weakly positive.

\begin{tabular}{|c|c|c|c|c|}
\hline Characteristic & 1 & 2 & 3 & 4 \\
\hline \multicolumn{5}{|l|}{ Decomposition of: } \\
\hline Aesculin & - & - & + & + \\
\hline Tyrosine & - & - & + & - \\
\hline Casein & + & - & - & $-{ }^{c *}$ \\
\hline Gelatin & + & - & - & - \\
\hline Growth in the presence of $6.5 \% \mathrm{NaCl}$ & + & $+{ }^{a}$ & + & + \\
\hline $\mathrm{H}_{2} \mathrm{~S}$ production & - & - & $-{ }^{b}$ & $-{ }^{c}$ \\
\hline \multicolumn{5}{|l|}{ Acid production (aerobically) from: } \\
\hline L-Arabinose & $\mathrm{W}$ & - & + & $-{ }^{c}$ \\
\hline D-Cellobiose & - & - & $+{ }^{b}$ & $+{ }^{c}$ \\
\hline D-Maltose & - & + & - & $+{ }^{c}$ \\
\hline D-Mannitol & - & + & + & + \\
\hline Glycerol & - & + & $-{ }^{b}$ & $-^{c}$ \\
\hline L-Rhamnose & + & $-{ }^{a}$ & $-{ }^{b}$ & $-{ }^{c}$ \\
\hline D-Raffinose & - & - & - & - \\
\hline Sucrose & - & + & $+{ }^{b}$ & - \\
\hline \multicolumn{5}{|c|}{ Utilization of substrate as sole carbon source (using Biolog GP2 MicroPlates) } \\
\hline Dextrin & + & - & - & - \\
\hline D-Gluconic acid & - & + & + & + \\
\hline$\alpha$-D-Glucose & - & + & - & + \\
\hline Maltotriose & + & - & - & - \\
\hline D-Mannose & - & + & + & + \\
\hline D-Psicose & - & + & + & + \\
\hline L-Rhamnose & + & - & - & - \\
\hline D-Sorbitol & - & + & - & - \\
\hline D-Tagatose & - & + & - & + \\
\hline Turanose & - & - & + & - \\
\hline$\gamma$-Hydroxybutyric acid & + & - & - & - \\
\hline L-Alaninamide & - & - & - & + \\
\hline Glycerol & + & + & - & - \\
\hline Adenosine & + & + & - & - \\
\hline $2^{\prime}$-Deoxyadenosine & + & - & - & + \\
\hline Inosine & + & - & - & - \\
\hline
\end{tabular}


Table 1. cont.

\begin{tabular}{|c|c|c|c|c|}
\hline Characteristic & 1 & 2 & 3 & 4 \\
\hline Thymidine & + & + & - & - \\
\hline D-Fructose 6-phosphate & - & - & + & - \\
\hline
\end{tabular}

${ }^{\star}$ Result not in line with data reported in the following studies: a, Zlamala et al. (2002); b, Wieser et al. (1999); c, Groth et al. (1996).

1976). The glycolic acid content of the bacterial cell wall was determined as described by Uchida \& Aida (1984). For cellular fatty acid analysis, the strain was grown on TSA medium at $30{ }^{\circ} \mathrm{C}$ for $36 \mathrm{~h}$ and fatty acid methyl ester analysis was performed using the Sherlock Microbial Identification System (MIDI) as described previously (Pandey et al., 2002). Freeze-dried cells for other chemotaxonomic analyses were prepared following growth of the strains in tryptic soy broth (HiMedia) for 4 days at $30^{\circ} \mathrm{C}$. Genomic DNA extraction and amplification, 16S rRNA gene sequencing and phylogenetic analysis were performed as described previously (Mayilraj et al., 2005). DNA-DNA hybridization was performed by the membrane filter method (Tourova \& Antonov, 1987). The G+C content of the genomic DNA was determined as described by Saha et al. (2005).

The organism had phenotypic properties, including chemical properties, that were consistent with its classification in the genus Agrococcus. The detailed differential physiological and biochemical properties are listed in Table 1 and further characteristics are given in the species description. The fatty acid compositions of strain $\mathrm{K} 22-21^{\mathrm{T}}$ and the type strains of the three Agrococcus species are detailed in Supplementary Table S1 in IJSEM Online. To elucidate the phylogenetic position of strain $\mathrm{K} 22-21^{\mathrm{T}}$ within the genus Agrococcus, an almost complete sequence of the 16S rRNA gene was determined (1454 bases). The 16S rRNA gene sequence of strain $\mathrm{K} 22-21^{\mathrm{T}}$ generated in this work was aligned with those of the other Agrococcus species retrieved from GenBank. A phylogenetic tree was constructed using the 16S rRNA gene sequences of the three Agrococcus type strains and strain $\mathrm{K} 22-21^{\mathrm{T}}$; Agromyces ramosus DSM $43045^{\mathrm{T}}$ was used as an outgroup. Strain K22-21 ${ }^{\mathrm{T}}$ formed a separate lineage within the genus Agrococcus (Fig. 1). 16S rRNA gene sequence similarities between strain $\mathrm{K} 22-21^{\mathrm{T}}$ and Agrococcus jenensis DSM $9580^{\mathrm{T}}$, Agrococcus baldri DSM $14215^{\mathrm{T}}$ and Agrococcus citreus DSM $12453^{\mathrm{T}}$ were $98 \cdot 5,96 \cdot 8$ and $96 \cdot 6 \%$, respectively. However, the DNA-DNA relatedness value between strain $\mathrm{K} 22-21^{\mathrm{T}}$ and Agrococcus jenensis was $55 \cdot 1 \%$, which is well below the $70 \%$ cut-off point recommended for the delineation of bacterial species (Wayne et al., 1987). DNADNA relatedness values between strain $\mathrm{K} 22-21^{\mathrm{T}}$ and the two other Agrococcus type strains were not determined, as it has been shown that organisms with more than $3 \% 16 \mathrm{~S}$ rRNA gene sequence dissimilarity belong to different genomic species (Stackebrandt \& Goebel, 1994). On the basis of the polyphasic data presented above, strain $\mathrm{K} 22-21^{\mathrm{T}}$ should be placed in the genus Agrococcus as a representative of a novel species; the name Agrococcus lahaulensis sp. nov. is proposed.

\section{Description of Agrococcus lahaulensis sp. nov.}

Agrococcus lahaulensis (la.haul.en'sis. N.L. masc. adj. lahaulensis pertaining to Lahaul Valley, located in the Indian Himalayas, where the type strain was isolated).

Gram-positive, non-acid-fast, aerobic bacterium. Forms lemon-coloured, circular, glistening, opaque colonies with an entire margin on TSA medium. Colony sizes are $0 \cdot 7-$ $3.0 \mathrm{~mm}$. Cells are irregularly spherical, occurring in pairs and clusters. Cells vary in size $(0 \cdot 6-1 \cdot 0 \mu \mathrm{m}$ wide by $1 \cdot 0-$ $1.5 \mu \mathrm{m}$ long). Does not form endospores. Non-motile. No mycelial growth phase is observed. Catalase-positive and oxidase-negative. Tolerates up to $7 \cdot 0 \% \mathrm{NaCl}$ and grows at temperatures between 25 and $37^{\circ} \mathrm{C}$, with optimum growth at $30^{\circ} \mathrm{C}$. Growth occurs at between pH 6 and 10; optimum growth is at $\mathrm{pH} 8 \cdot 0$. Positive for decomposition of casein, starch and gelatin. Negative for indole, urease and hydrogen sulfide production, methyl red and Voges-Proskauer reactions, utilization of citrate, decomposition of aesculin and tyrosine and nitrate reduction. Acid is produced from L-rhamnose, D-fructose and trehalose. Acid is produced weakly from L-arabinose, but not from D-cellobiose, myoinositol, D-mannitol, D-maltose, D-galactose, glycerol,

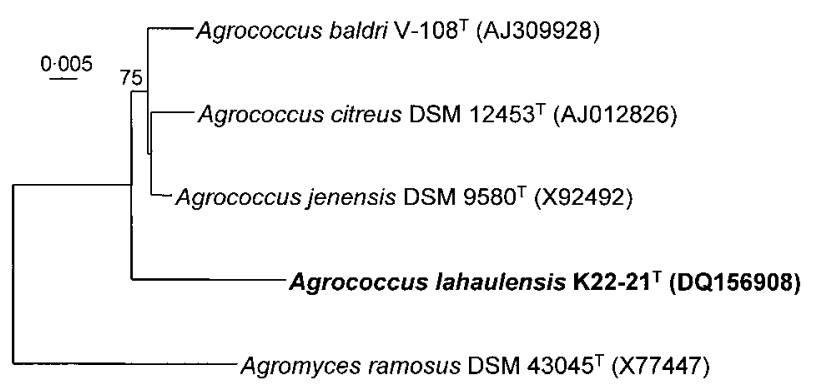

Fig. 1. Neighbour-joining tree based on 16S rRNA gene sequences (1454 bases) showing the phylogenetic relationships between strain $\mathrm{K} 22-21^{\top}$ and other species of the genus Agrococcus. Agromyces ramosus DSM $43045^{\top}$ was used as an outgroup. Bootstrap values (expressed as percentages of 1000 replications) greater than $50 \%$ are given at nodes. Bar, $0.5 \%$ sequence variation. 
salicin, sucrose or D-xylose. Utilization of various compounds as sole carbon sources is detailed in Table 1. The diagnostic cell wall diamino acid is diaminobutyric acid. The peptidoglycan contains Ala, Gly, Asp, Thr and diaminobutyric acid. The cell-wall sugars are glucose, rhamnose, ribose, mannose and galactose. The predominant lipids are diphosphatidylglycerol, phosphatidylglycerol, two unknown glycolipids and some non-characterized lipids. No mycolic acids are present. Contains major amounts of anteisobranched $\mathrm{C}_{15: 0}(48 \cdot 44 \%)$ and $\mathrm{C}_{17: 0}(27 \cdot 61 \%)$ fatty acids and iso-branched $\mathrm{C}_{15: 0}(9 \cdot 94 \%)$ and $\mathrm{C}_{16: 0}(5 \cdot 80 \%)$ fatty acids. The major menaquinones are MK-10, MK-11 and MK-12. The acyl type is acetyl.

The type strain is $\mathrm{K} 22-21^{\mathrm{T}}$ (=MTCC $7154^{\mathrm{T}}=\mathrm{DSM}$ $17612^{\mathrm{T}}$ ), isolated from soil, $0.45 \mathrm{~m}$ below an ice glacier, $4200 \mathrm{~m}$ above sea level, in Lahaul Valley, Himachal Pradesh, India. The $\mathrm{G}+\mathrm{C}$ content of strain $\mathrm{K} 22-21^{\mathrm{T}}$ is $74 \cdot 1 \mathrm{~mol} \%$.

\section{Acknowledgements}

We would like to thank Ms Gabi Poetter and Jennifer Gregor, DSMZ, Germany, and Mr Malkit Singh, MTCC, for their excellent technical assistance. Financial assistance from DBT and CSIR, Government of India is duly acknowledged. This is IMTECH communication number $57 / 2005$.

\section{References}

Cowan, S. T. \& Steel, K. J. (1965). Manual for the Identification of Medical Bacteria. London: Cambridge University Press.

Groth, I., Schumann, P., Weiss, N., Martin, K. \& Rainey, F. A. (1996). Agrococcus jenensis gen. nov., sp. nov., a new genus of actinomycetes with diaminobutyric acid in the cell wall. Int J Syst Bacteriol 46, 234-239.

Kroppenstedt, R. M. (1982). Separation of bacterial menaquinones by HPLC using reverse phase (RP 18) and a silver loaded ion exchanger as stationery phases. J Liq Chromatogr 5, 2359-2367.

Lanyi, B. (1987). Classical and rapid identification methods for medically important bacteria. Methods Microbiol 19, 1-67.

Mayilraj, S., Prasad, G. S., Suresh, K., Saini, H. S., Shivaji, S. \& Chakrabarti, T. (2005). Planococcus stackebrandtii sp. nov., isolated from a cold desert of the Himalayas, India. Int J Syst Evol Microbiol 55, 91-94.

Minnikin, D. E. \& Goodfellow, M. (1976). Lipid composition in the classification and identification of Nocardia and related taxa. In The Biology of the Nocardiaceae, pp. 160-219. Edited by M. Goodfellow, G. H. Brownell \& J. A. Serrano. London: Academic Press.

Minnikin, D. E., O'Donnell, A. G., Goodfellow, M., Alderson, G., Athalye, M., Schaal, K. \& Parlett, J. H. (1984). An integrated procedure for the extraction of bacterial isoprenoid quinones and polar lipids. J Microbiol Methods 2, 233-241.

Murray, R. G. E., Raymond, N., Doetsch, R. N. \& Robinow, C. F. (1994). Determinative and cytological light microscopy. In Methods for General and Molecular Bacteriology, pp. 21-41. Edited by P. Gerhardt, R. G. E. Murray, W. A. Wood \& N. R. Krieg. Washington, DC: American Society for Microbiology
Pandey, K. K., Mayilraj, S. \& Chakrabarti, T. (2002). Pseudomonas indica sp. nov., a novel butane-utilizing species. Int J Syst Evol Microbiol 52, 1559-1567.

Park, Y. H., Suzuki, K., Yim, D. G. \& 7 other authors (1993). Suprageneric classification of peptidoglycan group B actinomycetes by nucleotide sequencing of $5 \mathrm{~S}$ ribosomal RNA. Antonie van Leeuwenhoek 64, 307-313.

Rainey, F., Weiss, N., Prauser, H. \& Stackebrandt, E. (1994). Further evidence for phylogenetic coherence of actinomycetes with group Bpeptidoglycan and evidence for the phylogenetic intermixing of the genera Microbacterium and Aureobacterium as determined by $16 \mathrm{~S}$ rDNA analysis. FEMS Microbiol Lett 118, 135-139.

Saha, P., Krishnamurthi, S., Mayilraj, S., Prasad, G. S., Bora, T. C. \& Chakrabarti, T. (2005). Aquimonas voraii gen. nov., sp. nov., a novel gammaproteobacterium isolated from a warm spring of Assam, India. Int J Syst Evol Microbiol 55, 1491-1495.

Schleifer, K. H. \& Kandler, O. (1972). Peptidoglycan types of bacterial cell walls and their taxonomic implications. Bacteriol Rev 36, 407-477.

Smibert, R. M. \& Krieg, N. R. (1994). Phenotypic characterization. In Methods for General and Molecular Bacteriology, pp. 607-654. Edited by P. Gerhardt, R. G. E. Murray, W. A. Wood \& N. R. Krieg. Washington, DC: American Society for Microbiology.

Smith, N. R., Gordon, R. E. \& Clark, F. E. (1952). Aerobic sporeforming bacteria. Agricultural Monograph no. 16. Washington, DC: US Department of Agriculture.

Stackebrandt, E. \& Goebel, B. M. (1994). Taxonomic note: a place for DNA-DNA reassociation and $16 \mathrm{~S}$ rRNA sequence analysis in the present species definition in bacteriology. Int J Syst Bacteriol 44, 846-849.

Stackebrandt, E., Rainey, F. A. \& Ward-Rainey, N. (1997). Proposal for a new hierarchic classification system, Actinobacteria classis nov. Int J Syst Bacteriol 47, 479-491.

Staneck, J. L. \& Roberts, G. D. (1974). Simplified approach to identification of aerobic actinomycetes by thin-layer chromatography. Appl Microbiol 28, 226-231.

Suzuki, K., Sasaki, J., Uramoto, M., Nakase, T. \& Komagata, K. (1997). Cryobacterium psychrophilum gen. nov., sp. nov., nom. rev., comb. nov., an obligately psychrophilic actinomycete to accommodate 'Curtobacterium psychrophilum' Inoue and Komagata 1976. Int J Syst Bacteriol 47, 474-478.

Tourova, T. P. \& Antonov, A. S. (1987). Identification of microorganisms by rapid DNA-DNA hybridization. Methods Microbiol 19, 333-355.

Uchida, K. \& Aida, K. (1984). An improved method for the glycolate test for simple identification of the acyl type of bacterial cell walls. J Gen Appl Microbiol 30, 131-134.

Wayne, L. G., Brenner, D. J., Colwell, R. R. \& 9 other authors (1987). International Committee on Systematic Bacteriology. Report of the ad hoc committee on reconciliation of approaches to bacterial systematics. Int J Syst Bacteriol 37, 463-464.

Wieser, M., Schumann, P., Martin, K., Altenburger, P., Burghardt, J., Lubitz, W. \& Busse, H.-J. (1999). Agrococcus citreus sp. nov., isolated from a medieval wall painting of the chapel of Castle Herberstein (Austria). Int J Syst Bacteriol 49, 1165-1170.

Zlamala, C., Schumann, P., Kämpfer, P., Rosselló-Mora, R., Lubitz, W. \& Busse, H.-J. (2002). Agrococcus baldri sp. nov., isolated from the air in the 'Virgilkapelle' in Vienna. Int J Syst Evol Microbiol 52, 1211-1216. 